\title{
Primary Brain Calcification Causal PiT2 Transport-Knockout Variants can Exert Dominant Negative Effects on Wild-Type PiT2 Transport Function in Mammalian Cells
}

\author{
Frederik Tibert Larsen ${ }^{1}$ • Nina Jensen ${ }^{1,2}$ - Jacob Kwasi Autzen ${ }^{1}$. \\ Iben Boutrup Kongsfelt ${ }^{1}$ • Lene Pedersen ${ }^{1,2}$ iD
}

Received: 9 October 2016 / Accepted: 22 November 2016/Published online: 9 December 2016

(C) The Author(s) 2016. This article is published with open access at Springerlink.com

\begin{abstract}
Primary brain calcification (PBC) is a neurodegenerative disorder characterized by calcium-phosphate deposits in the basal ganglia and often also other areas of the brain. The prevalent clinical manifestations are cognitive impairment, neuropsychiatric symptoms, and movement disorders. In recent years, monoallelic variants in SLC20A2, which encodes the type III sodium-dependent inorganic phosphate $\left(\mathrm{P}_{\mathrm{i}}\right)$ transporter 2 (PiT2), have been linked to the familial form of PBC in $40-50 \%$ of the families reported worldwide as well as to sporadic cases of PBC. Further insight into the disease mechanism is, however, needed. Based on co-expression studies of wild-type and variant PiT2 in Xenopus laevis oocytes, the molecular disease mechanism associated with SLC2OA2 missense variants has formerly been suggested to be haploinsufficiency. We have here used mammalian cells iso-

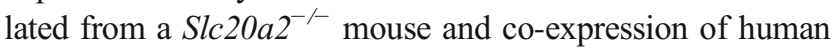
wild-type and variant PiT2. Two of the variants studied have both been reported twice in unrelated PBC cases: PiT2D28N in two sporadic cases and PiT2E575K in a familial and a sporadic case. We find that in mammalian cells, the analyzed SLC20A2 missense variants can exert their effect in a dominant negative manner resulting in decreased wild-type PiT2 $\mathrm{P}_{\mathrm{i}}$ transport. Thus, compared to monoallelic lack of functional PiT2 protein expression, which reasonably points towards haploinsufficiency, certain $S L C 20 A 2$ missense variants may be more detrimental for cellular $\mathrm{P}_{\mathrm{i}}$ uptake and potentially
\end{abstract}

Lene Pedersen

LP@mbg.au.dk

1 Department of Molecular Biology and Genetics, Aarhus University, C. F. Møllers Allé 3, Building 1130, 8000 Aarhus, Denmark

2 Department of Clinical Medicine, Aarhus University, Aarhus, Denmark contribute to an earlier disease onset and/or a more severe phenotype as observed for Slc20a2 $2^{-/-}$mice compared to Slc20a2 $2^{+-}$mice.

Keywords $S L C 20 A 2$ - Primary familial brain calcification . Phosphate transporter $\cdot$ PiT2 $\cdot$ Oligomerization

\section{Introduction}

Primary familial brain calcification (PFBC) (OMIM: \#213600, \#616413, \#615007, and \#615483), formerly known as "Fahr's disease" or familial idiopathic basal ganglia calcification (FIBGC), is a rare autosomal dominant inherited neurodegenerative disease. It is characterized by bilateral calcifications in the basal ganglia, but other areas of the brain are also often affected. Primary refers to that the calcifications are not secondary to systemic diseases, infections, traumas, or toxicity (Sobrido et al. 2014; Westenberger and Klein 2014). The symptoms associated with PFBC are heterogeneous with the most prevalent being cognitive impairment (ranging from mild cognitive impairment to dementia), neuropsychiatric symptoms (e.g., mood disorders and psychotic signs), and movement disorders (often parkinsonism), but other symptoms as migraine and speech disorders can also be present (Manyam et al. 2001; Nicolas et al. 2013a; Sobrido et al. 2014; Yamada et al. 2014; Nicolas et al. 2015). The age of onset of clinical symptoms is also diverse and ranges from early childhood to old age (Nicolas et al. 2013a; Sobrido et al. 2014; Nicolas et al. 2015).

The gene SLC20A2 encodes a member of the inorganic phosphate $\left(\mathrm{P}_{\mathrm{i}}\right)$ transport (PiT) family (TC\#2.A.20), the type III sodium-dependent $\mathrm{P}_{\mathrm{i}}$ transporter 2 (PiT2) (Kavanaugh et al. 1994; Kavanaugh and Kabat 1996; Bai et al. 2000). PiT2 is ubiquitously expressed in mammalian cells and 
assigned a role in cellular $P_{i}$ homeostasis and, recently, in maintaining the lower $P_{i}$ concentration in the cerebrospinal fluid (CSF) compared to the blood (Kavanaugh et al. 1994; Uckert et al. 1998; Guerreiro et al. 2014; Jensen et al. 2016). In 2012, Wang et al. linked a deletion and five missense variants in SLC20A2, all resulting in PiT2 proteins with impaired $\mathrm{P}_{\mathrm{i}^{-}}$ transport function, as well as a $S L C 20 A 2$ frameshift variant to PFBC (Wang et al. 2012). It was later confirmed that knockout (KO) of PiT2 in mice indeed led to brain calcifications, which could be found associated with the vasculature as observed in autopsied PFBC patients (Miklossy et al. 2005; Wider et al. 2009; Jensen et al. 2013). Variants in three other genes have also been associated with PFBC: the genes encoding the platelet-derived growth factor receptor $\beta$ (PDGF-R $\beta$ ) and its main ligand, PDGF-B (Keller et al. 2013; Nicolas et al. 2013b), and lately, the gene encoding the $P_{i}$ exporter, XPR1 (Legati et al. 2015). SLC20A2 variants are present in 40 to $50 \%$ of the PFBC families (Hsu et al. 2013; Yamada et al. 2014), which makes variants in this gene a prime cause of PFBC. In addition, SLC20A2 variants are also linked to sporadic cases of primary brain calcification (PBC), confirmed or not confirmed as de novo variants (Schottlaender et al. 2012; Chen et al. 2013; Nicolas et al. 2013a; Ferreira et al. 2014; Westenberger and Klein 2014; Lemos et al. 2015).

Human PiT2 (NP_006740.1) is a 652-amino acid long protein (van Zeijl et al. 1994). The N- and C-terminal parts are multi-membrane spanning and connected with a large intracellular domain comprising approximately half the protein (van Zeijl et al. 1994). Since 2012, various kinds of variants in SLC20A2 have been reported linked to familial and sporadic PBCs, e.g., missense, frameshift, deletions, nonsense, and splice site (Schottlaender et al. 2012; Wang et al. 2012; Chen et al. 2013; Hsu et al. 2013; Lemos et al. 2013; Nicolas et al. 2013a; Ferreira et al. 2014; Taglia et al. 2014; Westenberger and Klein 2014; Yamada et al. 2014; Lemos et al. 2015; Nicolas et al. 2015; Liu et al. 2016). They are in general scattered over the coding sequence with the exception of exon 6 , which is predicted to encode the transmembrane region positioned immediately $\mathrm{N}$-terminal to the large intracellular domain (Bøttger and Pedersen 2011; Westenberger and Klein 2014; Lemos et al. 2015). More than 50\% of the presently reported $S L C 20 A 2$ variant types are missense variants (Westenberger and Klein 2014; Lemos et al. 2015). Of these, the missense variants p.Asp28Asn (PiT2D28N) and p.Glu575Lys (PiT2E575K) had previously been investigated and shown not to support $\mathrm{P}_{\mathrm{i}}$ uptake in Xenopus laevis oocytes (Bøttger and Pedersen 2002, 2005); D28 and E575 were originally selected for investigation due to their high degree of phylogenetic conservation with D28 being part of the Nterminal PiT family signature sequence (Bøttger and Pedersen 2002, 2005). In their seminal study of PFBC families reported in 2012, Wang et al. identified PiT2E575K as well as additional SLC2OA2 missense variants, which they also found not to support $\mathrm{P}_{\mathrm{i}}$ uptake in Xenopus oocytes (Wang et al. 2012). The authors furthermore analyzed whether PiT2E575K and the missense variant p.Ser601Trp (PiT2S601W) acted in dominant negative manners on the $\mathrm{P}_{\mathrm{i}^{-}}$ uptake function of wild-type (WT) PiT2 by co-injection of complementary RNAs encoding WT PiT2 and either of the two variants at a 1:1 ratio and found this not to be the case (Wang et al. 2012). Therefore, the general view of how $S L C 20 A 2$ variants can lead to disease is by haploinsufficiency (Westenberger and Klein 2014; Lemos et al. 2015). In the cases where there is no protein expression from the variant allele, haploinsufficiency is the likely disease mechanism. It has, however, been shown that PiT2 can form functional oligomers in mammalian cells and, using $\mathrm{P}_{\mathrm{i}}$-transport-incompetent PiT2 proteins, that the oligomerization per se is independent of PiT2's $\mathrm{P}_{\mathrm{i}}$-transport ability (Salaün et al. 2002; Salaün et al. 2004). Moreover, kinetic analysis of human PiT2 expressed in Xenopus oocytes by Bøttger et al. revealed positive cooperativity (Hill coefficient of 2) (Bøttger et al. 2006), thus further suggesting that the transporting form of PiT2 is a dimer. It can, however, also be observed that the molecular weight of human PiT2 oligomers isolated from Xenopus oocytes seems to be lower than that of oligomers isolated from mammalian cells (Bøttger and Pedersen 2002; Salaün et al. 2002; Salaün et al. 2004; Bøttger and Pedersen 2005), which might implicate, e.g., post-translational processing in mammalian cells. There are indeed differences between Xenopus oocytes and mammalian cells, e.g., in membrane composition and expression levels of endogenous proteins (Wagner et al. 2000; Hill et al. 2005). Thus, albeit that $\mathrm{P}_{\mathrm{i}}$-transport-incompetent PiT2 variants linked to $\mathrm{PBC}$ have been reported not to affect the $\mathrm{P}_{\mathrm{i}}$-transport of WT PiT2 in Xenopus oocytes, we wished to address whether $\mathrm{P}_{\mathrm{i}}$-transport-incompetent PiT2 variants can have a dominant negative effect in mammalian cells.

\section{Materials and Methods}

\section{Cells}

C57BL/6N $\mathrm{N}^{\mathrm{Tac}}-$ Slc20a2 $2^{\mathrm{tm} 1 \mathrm{a}(\mathrm{EUCOMM}) \mathrm{Wtsi}} / \mathrm{Ieg}$ (EM:05549) $\left(\right.$ Slc20a2 $\left.2^{+-}\right)$mice obtained from the European Mouse Mutant Archive (EMMA) in Germany have been described previously (http://www.knockoutmouse. org/martsearch/project/24503) (Jensen et al. 2013). The mice were handled according to the Danish law on animal experimentation and the animal welfare policy at Aarhus University. The strain is heterozygous for the KO cassette, L1L2-PGK-P, which introduces splice acceptor and SV40 polyadenylation sequences in Slc20a2 between the third and fourth exons (i.e., the second and third coding exons). Skin fibroblasts (3463T3) were obtained from a mouse homozygous for the $\mathrm{KO}$ cassette $\left(\mathrm{Slc2Oa^{-/ }}\right.$ mice); further characterization of the Slc20a 
cells will be published elsewhere. The cells were cultivated in Dulbecco's modified eagle's medium (DMEM) with pyruvate (Gibco, Life Technologies) supplemented with $15 \%$ fetal bovine serum (Gibco) and $1 \%$ penicillin and streptomycin (Gibco).

\section{Transfection}

The eukaryotic expression vector pcDNA $1 A^{R}$ tkpA encoding WT human PiT2 (pOJ74) or $\mathrm{P}_{\mathrm{i}}$-transport-KO mutants (pOJ74D28N, pOJ74H502A, and pOJ74E575K) have been described (Pedersen et al. 1995; Bøttger and Pedersen 2002, 2005, 2011). Cells were seeded in four-well plates (NUNC, Hounisen) at a density of $1.5 \times 10^{4}$ cells $/ \mathrm{cm}^{2}$ and incubated for $24 \mathrm{~h}$ before they were transfected using the Lipofectamine ${ }^{\circledR} 2000$ reagent (Invitrogen ${ }^{\mathrm{TM}}$, Thermo Fisher Scientific) at a DNA/transfection reagent ratio of $1: 3$. This optimal ratio for transfection was determined by transfecting the cells with a eukaryotic expression vector encoding enhanced green fluorescent protein (pEGFP-N1 (Clontech)). DNAs of similar quality of pOJ74 and pOJ74D28N, pOJ74H502A, or pOJ74E575K were mixed in equimolar or different ratios. In order to avoid promotor competition, empty vector DNA, pcDNA1 $\mathrm{A}^{\mathrm{R}} \mathrm{tkpA}$, was added to obtain equimolar quantities of CMV-promotorcontaining constructs. In addition, pUC19 DNA was added to obtain a final concentration of $2.5 \mu \mathrm{g}$ of DNA per well. Mock-transfected cells were transfected with empty vector DNA, pcDNA1 $\mathrm{A}^{\mathrm{R}} \mathrm{tkpA}$. The transfections were performed according to the manufacturer's instructions.

\section{Phosphate Uptake}

Cells seeded in four-well plates and transfected as described above were incubated for $48 \mathrm{~h}$ after the transfection. The cells were washed in $37^{\circ} \mathrm{C}$ pre-warmed $\mathrm{P}_{\mathrm{i}}$-free DMEM medium (Gibco) and thereafter incubated at room temperature for 5 min in $37^{\circ} \mathrm{C}$ pre-warmed $\mathrm{P}_{\mathrm{i}}$-free DMEM supplemented with $\mathrm{KH}_{2}{ }^{32} \mathrm{PO}_{4}\left(\mathrm{NEX} 060,1 \mathrm{Ci} / \mathrm{mmol}\right.$, Perkin Elmer) and cold $\mathrm{P}_{\mathrm{i}}$ added to a final concentration of $1 \mathrm{mM} \mathrm{P}_{\mathrm{i}}$. They were then washed in $3 \times$ ice-cold $0.9 \% \mathrm{NaCl}$ and lysed with $0.5 \%$ Triton $\mathrm{X}-100$. One third of each lysate was transferred to counting vials, mixed with $5 \mathrm{~mL}$ liquid scintillation cocktail (Optiphase Hisafe 3 (Perkin Elmer)), and counted in a liquid scintillation counter. Dilution series of ${ }^{32} \mathrm{P}_{\mathrm{i}}$ were counted simultaneously. The remaining lysates were stored at $-20{ }^{\circ} \mathrm{C}$ for later protein determination using the $\mathrm{BCA}^{\mathrm{TM}}$ Protein Assay Kit (Pierce).

\section{Statistics}

Data are presented as mean \pm standard deviation (SD). As these types of experiments can be prone to large variations, the modified Thompson tau technique was applied; one outlier in the experiment shown in Fig. $1 \mathrm{~b}$ was discarded $(p \leq 0.01)$. The hypothesis that two mean values were identical was tested by a two-tailed Student's $t$ test; a $p$ value $\leq 0.05$ was considered statistically significant. Bonferroni-Holm correction was performed to avoid $\alpha$-error accumulation (Holm 1979).

\section{Results}

In order to address whether a $\mathrm{P}_{\mathrm{i}}$-transport-incompetent PiT2 variant can affect the $\mathrm{P}_{\mathrm{i}}$-transport function of the WT PiT2 protein in mammalian cells, we used PiT2E575K, which has been reported in a Spanish family as well as in a sporadic case and experimentally verified to be $\mathrm{P}_{\mathrm{i}}$-transport incompetent (Bøttger and Pedersen 2002; Schottlaender et al. 2012; Wang et al. 2012). To simulate the effect of a monoallelic variant in the SLC20A2 gene and thus mimic the PBC disease situation, we used cells (3463T3) isolated from a Slc20a $a^{-/-}$mouse and co-transfection of vectors expressing variant and WT human PiT2 proteins; the 3463 T3 cells do not express endogenous PiT2 in the plasma membrane (Jensen et al. submitted manuscript). Transient transfection of the expression vector encoding WT PiT2 (pOJ74) was sufficient to obtain an increased $\mathrm{P}_{\mathrm{i}}$-uptake ability of $3463 \mathrm{~T} 3$ cultures (compare pOJ74 and mock- and non-transfected in Fig. 1). Co-transfection of the WT PiT2-encoding vector (pOJ74) with equimolar amounts $(1: 1)$ or three $(1: 3)$ or four (1:4) times more of the PiT2E575K-encoding vector (pOJ74E575K), however, resulted in significant decreases in the $\mathrm{P}_{\mathrm{i}}$-uptake ability of the cultures compared to cultures transfected with only WT PiT2-encoding vector (pOJ74) (Fig. 1a). To analyze whether the presence of PiT2 proteins with other missense variants can mitigate the WT PiT2-mediated $\mathrm{P}_{\mathrm{i}}$-uptake ability when expressed in a mammalian cell, PiT2D28N and PiT2H502A were employed. The $\mathrm{D} 28 \mathrm{~N}$ variant has been reported in two sporadic cases of PBC (Chen et al. 2013; Nicolas et al. 2013a), and the H502A mutation was employed to represent a reported variant of $\mathrm{H} 502$ in PFBC (H502Q in PFBC) (Hsu et al. 2013). Both PiT2D28N and PiT2H502A have been shown to be unable to support $\mathrm{P}_{\mathrm{i}}$ uptake in Xenopus oocytes (Bøttger and Pedersen 2005, 2011). Like E575 and D28, H502 also shows a high degree of phylogenetic conservation, and it is part of the $\mathrm{C}$ terminal PiT family signature sequence. Co-transfection of equimolar amounts (1:1) of the PiT2D28N- or PiT2H502A-encoding vectors (pOJ74D28N and pOJ74H502A, respectively) with the WT PiT2-encoding vector (pOJ74) also resulted in significant decreases in the $\mathrm{P}_{\mathrm{i}}$-uptake ability of the cultures compared to cultures transfected with only WT PiT2-encoding vector (pOJ74) (Fig. 1b). Hence, these results show that the presence of a 

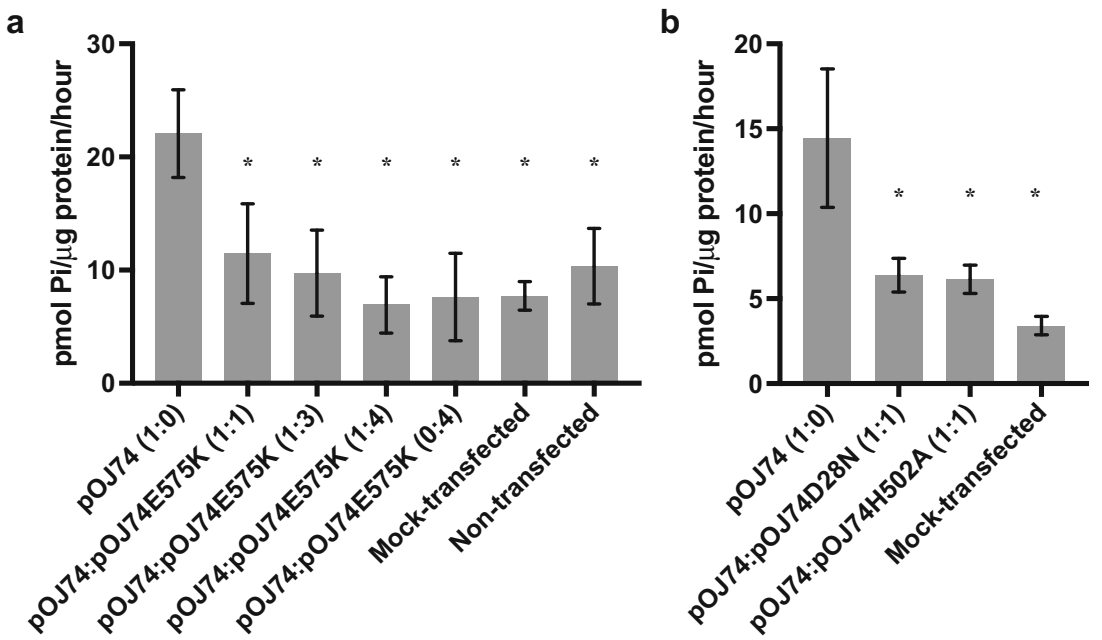

Fig. 1 Co-expression assays. Cells were seeded at $1.5 \times 10^{4}$ cells $/ \mathrm{cm}^{2}$ in four-well plates. The following day, they were transfected with WT PiT2encoding vector, pOJ74, and vectors encoding the $\mathrm{P}_{\mathrm{i}}$-transportincompetent a PiT2E575K (pOJ74E575K) or b PiT2D28N (pOJ74D28N) or PiT2H502A (pOJ74H502A) as indicated. Mocktransfected: cells transfected with empty vector DNA. Ratios refer to the ratio between vectors encoding WT and $\mathrm{P}_{\mathrm{i}}$-transport-incompetent PiT2, where 1 represents $0.05 \mu \mathrm{g}$ DNA. Emtpy expression vector and plasmid DNAs were included to ensure equimolar amounts of expression vector and same amount of DNA, respectively, in the transfections. Approximately $48 \mathrm{~h}$ after transfection, the cells were incubated in transport medium containing a total $\left[\mathrm{P}_{\mathrm{i}}\right]$ of $1 \mathrm{mM}$ and the import of ${ }^{32} \mathrm{P}_{\mathrm{i}}$ was analyzed over $5 \mathrm{~min}$. Results are shown as mean $P_{i}$ uptake per microgram protein per hour of at least three wells; error bars represent SDs. Asterisk indicates $p \leq 0.05$ relative to cells expressing WT PiT2 only (pOJ74 (1:0) (leftmost column))
$\mathrm{P}_{\mathrm{i}}$-transport-incompetent PiT2 protein can exert a dominant negative effect on WT PiT2-mediated $\mathrm{P}_{\mathrm{i}}$-uptake in mammalian cells.

\section{Discussion}

The here observed dominant negative effects of $\mathrm{P}_{\mathrm{i}}$-transport-incompetent PiT2 proteins on WT PiT2 $\mathrm{P}_{\mathrm{i}}$-transport function, when transfected in equimolar amounts, show that expression of PiT2 variants associated with familial and sporadic PBCs can exert dominant negative effects on WT PiT2 $\mathrm{P}_{\mathrm{i}}$-transport function in mammalian cells. Thus, these results suggest that in association with $\mathrm{PBC}$, the investigated variants can result in a more severely impaired cellular $\mathrm{P}_{\mathrm{i}}$-transport function than mere lack of expression of a functional protein from one allele, i.e., haploinsufficiency.

PiT2 is also a receptor for gammaretroviruses (Kavanaugh et al. 1994; Miller and Miller 1994; van Zeijl et al. 1994), and all PiT2-derived proteins analyzed in the present study support gammaretroviral infection in mammalian cells (Bøttger and Pedersen 2002, 2005, 2011), which is interpreted as they can be inserted "correctly" in the plasma membrane. Since former characterization studies suggest that WT PiT2 proteins form functional oligomers (Salaün et al. 2002; Bøttger et al. 2006) and that oligomerization is independent of their $\mathrm{P}_{\mathrm{i}}$-transport function per se (Salaün et al. 2004), we suggest that oligomerization of WT and $\mathrm{P}_{\mathrm{i}}$-transport-incompetent PiT2 proteins is the underlying basis for the dominant negative effect on WT PiT2 $\mathrm{P}_{\mathrm{i}}$-transport function observed in the present study.

A recent publication on an autopsied $\mathrm{PFBC}$ patient heterozygous for a $S L C 20 \mathrm{~A} 2$ missense variant (p.Ser637Arg) reported in two Japanese families is indeed congruent with a dominant negative effect exerted by a PiT2 variant protein (Yamada et al. 2014; Kimura et al. 2015). Kimura et al. found PiT2 expression to range from severely reduced to absent in samples from the frontal cortex, putamen, and cerebellum, i.e., the PiT2 protein amount was more than halved. Mere haploinsufficiency is expected to lead to at the most halved expression levels or less than halved due to putative compensatory upregulation of expression. The most likely explanation for the severely reduced PiT2 amount reported for the patient is that WT PiT2 protein oligomerized with the variant PiT2 protein is recognized as a misfolded confirmation by the cells and degraded.

Both the PiT2E575K and the PiT2D28N variants analyzed here have been found in two independent cases, which are likely unrelated based on their ethnic origin (Schottlaender et al. 2012; Wang et al. 2012; Chen et al. 2013; Nicolas et al. 2013a; Westenberger and Klein 2014; Lemos et al. 2015). Nevertheless, the small number of PFBC and sporadic $\mathrm{PBC}$ cases linked to the various $S L C 20 A 2$ variant types and the high degree of variation in onset of symptoms and their severity, even within PFBC families (Hsu et al. 2013; Nicolas 
et al. 2013a; Westenberger and Klein 2014; Yamada et al. 2014; Lemos et al. 2015; Nicolas et al. 2015), make studies of variant-phenotype correlations difficult. However, results from in vitro studies, as the present study, and animal studies can provide insight into potential disease mechanisms and the specific roles of PiT2. It was recently shown by Jensen et al.

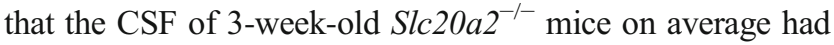
more than twofold elevated $\left[\mathrm{P}_{\mathrm{i}}\right]$ compared to WT mice (Jensen et al. 2016). Wallingford et al. have later reported similar find-

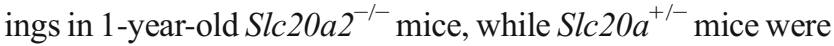
found to show an intermediate $\operatorname{CSF}\left[\mathrm{P}_{\mathrm{i}}\right]$ albeit not statistically significantly different from WT mice (Wallingford et al. 2016). The elevated $\left[\mathrm{P}_{\mathrm{i}}\right]$ in the CSF is ascribed to a function of PiT2 in the choroid plexus as an exporter of $\mathrm{P}_{\mathrm{i}}$ from the CSF (Guerreiro et al. 2014; Jensen et al. 2016; Wallingford et al. 2016). In PBC patients, a missense variant exerting a dominant negative effect could result in a potentially more severe outcome than haploinsufficiency with respect to elevation of the CSF $\left[\mathrm{P}_{\mathrm{i}}\right]$ as well as with respect to the putative direct effect on the cells of the brain. In addition, compared

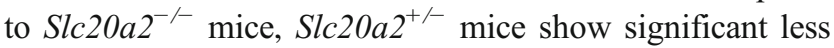
(Wallingford et al. 2016) or rarely (Jensen et al. submitted manuscript) brain calcification and at later ages (Jensen et al. 2013; Wallingford et al. 2016) (Jensen et al. submitted manuscript). And while there is a high degree of variation in the degree of calcification and the manifestation of symptoms even within PFBC families (Hsu et al. 2013; Nicolas et al. 2013a; Westenberger and Klein 2014; Yamada et al. 2014; Lemos et al. 2015; Nicolas et al. 2015), there is a correlation between the total calcification score and presence of symptoms (Nicolas et al. 2013a; Nicolas et al. 2015). Thus, missense variants exerting a dominant negative effect might contribute to an earlier disease onset and/or a more serious phenotype than variants, which cause monoallelic lack of expression of functional protein.

In conclusion, our results strongly indicate that the molecular mechanism of disease in familial and sporadic PBCs might not be ascribed solely to haploinsufficiency. Missense variants in SLC2OA2 linked to the disease have here been shown to exert a dominant negative effect on WT PiT2mediated cellular $\mathrm{P}_{\mathrm{i}}$ uptake. PiT2 proteins can oligomerize, and the variant proteins might exert their dominant negative effect, either by reducing the amount of $\mathrm{P}_{\mathrm{i}}$-transport-capable PiT2 oligomers in the cell membrane and/or, as observed by Kimura et al. (Kimura et al. 2015) in a PFBC patient, by reducing the amount of WT and variant PiT2 proteins in the cells.

Acknowledgments We thank the animal technicians and veterinarians at the animal facility at the Health Faculty, Aarhus University, for excellent caretaking of the animals.

NJ was in part sponsored by the Graduate School of Health at Aarhus University and the Danish Heart Foundation [grant number 15-R99-
A5905-22947]. IBK was in part sponsored by the Graduate School of Science and Technology at Aarhus University.

\section{Compliance with Ethical Standards}

Author Contributions FTL participated in designing the study, characterized the cells, performed the experiments, and drafted the manuscript.

NJ participated in designing the study, handled the mice, performed genotyping, established the cell cultures, and helped with writing the manuscript.

JKA participated in characterizing the cells and helped with writing the manuscript.

IBK participated in designing the study and establishing methods and helped with writing the manuscript.

LP participated in designing the study, coordinated the research and supervised the project, and helped with writing the manuscript.

Competing Interests The authors declare that they have no conflict of interest.

Open Access This article is distributed under the terms of the Creative Commons Attribution 4.0 International License (http:// creativecommons.org/licenses/by/4.0/), which permits unrestricted use, distribution, and reproduction in any medium, provided you give appropriate credit to the original author(s) and the source, provide a link to the Creative Commons license, and indicate if changes were made.

\section{References}

Bai L, Collins JF, Ghishan FK (2000) Cloning and characterization of a type III Na-dependent phosphate cotransporter from mouse intestine. Am J Physiol Cell Physiol 279:C1135-C1143

Bøttger P, Hede SE, Grunnet M, Høyer B, Klærke DA, Pedersen L (2006) Characterization of transport mechanisms and determinants critical for Na+-dependent Pi symport of the PiT family paralogs human PiT1 and PiT2. Am J Physiol Cell Physiol 291:C1377-C1387. doi:10.1152/ajpcell.00015.2006

Bøttger P, Pedersen L (2002) Two highly conserved glutamate residues critical for type III sodium-dependent phosphate transport revealed by uncoupling transport function from retroviral receptor function. $\mathrm{J}$ Biol Chem 277:42741-42747. doi:10.1074/jbc.M7096200

Bøttger P, Pedersen L (2005) Evolutionary and experimental analyses of inorganic phosphate transporter PiT family reveals two related signature sequences harboring highly conserved aspartic acids critical for sodium-dependent phosphate transport function of human PiT2. FEBS J 272:3060-3074. doi:10.1111/j.1742-4658.2005.04720.x

Bøttger P, Pedersen L (2011) Mapping of the minimal inorganic phosphate transporting unit of human PiT2 suggests a structure universal to PiT-related proteins from all kingdoms of life. BMC Biochem 12: 21. doi:10.1186/1471-2091-12-21

Chen WJ, Yao XP, Zhang QJ, Ni W, He J, Li HF et al (2013) Novel SLC20A2 mutations identified in southern Chinese patients with idiopathic basal ganglia calcification. Gene 529:159-162. doi:10.1016/j.gene.2013.07.071

Ferreira JB, Pimentel L, Keasey MP, Lemos RR, Santos LM, Oliveira MF et al (2014) First report of a de novo mutation at SLC20A2 in a patient with brain calcification. J Mol Neurosci 54:748-751. doi:10.1007/s12031-014-0357-9

Guerreiro PM, Bataille AM, Parker SL, Renfro JL (2014) Active removal of inorganic phosphate from cerebrospinal fluid by 
the choroid plexus. Am J Physiol Renal Physiol 306:F1275F1284. doi:10.1152/ajprenal.00458.2013

Hill WG, Southern NM, MacIver B, Potter E, Apodaca G, Smith CP et al (2005) Isolation and characterization of the Xenopus oocyte plasma membrane: a new method for studying activity of water and solute transporters. Am J Physiol Renal Physiol 289:F217-F224. doi:10.1152/ajprenal.00022.2005

Holm S (1979) A simple sequentially rejective multiple test procedure. Scand J Statist 6:65-70

Hsu SC, Sears RL, Lemos RR, Quintáns B, Huang A, Spiteri E et al (2013) Mutations in SLC20A2 are a major cause of familial idiopathic basal ganglia calcification. Neurogenetics 14:11-22. doi:10.1007/s10048-012-0349-2

Jensen N, Autzen JK, Pedersen L (2016) Slc20a2 is critical for maintaining a physiologic inorganic phosphate level in cerebrospinal fluid. Neurogenetics 17:125-130. doi:10.1007/s10048-015-0469-6

Jensen N, Schrøder HD, Hejbøl EK, Füchtbauer EM, de Oliveira JR, Pedersen L (2013) Loss of function of Slc20a2 associated with familial idiopathic basal ganglia calcification in humans causes brain calcifications in mice. J Mol Neurosci 51:994-999. doi:10.1007/s12031-013-0085-6

Kavanaugh MP, Kabat D (1996) Identification and characterization of a widely expressed phosphate transporter/retrovirus receptor family. Kidney Int 49:959-963

Kavanaugh MP, Miller DG, Zhang W, Law W, Kozak SL, Kabat D et al (1994) Cell-surface receptors for gibbon ape leukemia virus and amphotropic murine retrovirus are inducible sodium-dependent phosphate symporters. Proc Natl Acad Sci U S A 91:7071-7075

Keller A, Westenberger A, Sobrido MJ, Garcia-Murias M, Domingo A, Sears RL et al (2013) Mutations in the gene encoding PDGF-B cause brain calcifications in humans and mice. Nat Genet 45: 1077-1084. doi:10.1038/ng.2723

Kimura T, Miura T, Aoki K, Saito S, Hondo H, Konno T et al (2015) Familial idiopathic basal ganglia calcification: histopathologic features of an autopsied patient with an SLC20A2 mutation. Neuropathology 36:365-371. doi:10.1111/neup.12280

Legati A, Giovannini D, Nicolas G, Lopez-Sanchez U, Quintans B, Oliveira JR et al (2015) Mutations in XPR1 cause primary familial brain calcification associated with altered phosphate export. Nat Genet 47:579-581. doi:10.1038/ng.3289

Lemos RR, Oliveira MF, Oliveira JR (2013) Reporting a new mutation at the SLC20A2 gene in familial idiopathic basal ganglia calcification. Eur J Neurol 20:e43-e44. doi:10.1111/ene.12044

Lemos RR, Ramos EM, Legati A, Nicolas G, Jenkinson EM, Livingston $\mathrm{JH}$ et al (2015) Update and mutational analysis of SLC20A2: a major cause of primary familial brain calcification. Hum Mutat 36: 489-495. doi:10.1002/humu.22778

Liu X, Ma G, Zhao Z, Mao F, Tang J, Li X et al (2016) Novel mutation of SLC20A2 in a Chinese family with primary familial brain calcification. J Neurol Sci 360:1-3. doi:10.1016/j.jns.2015.11.036

Manyam BV, Walters AS, Narla KR (2001) Bilateral striopallidodentate calcinosis: clinical characteristics of patients seen in a registry. Mov Disord 16:258-264

Miklossy J, Mackenzie IR, Dorovini-Zis K, Calne DB, Wszolek ZK, Klegeris A et al (2005) Severe vascular disturbance in a case of familial brain calcinosis. Acta Neuropathol 109:643-653. doi:10.1007/s00401-005-1007-7

Miller DG, Miller AD (1994) A family of retroviruses that utilize related phosphate transporters for cell entry. J Virol 68:8270-8276

Nicolas G, Charbonnier C, de Lemos RR, Richard AC, Guillin O, Wallon $D$ et al (2015) Brain calcification process and phenotypes according to age and sex: lessons from SLC20A2, PDGFB, and PDGFRB mutation carriers. Am J Med Genet B Neuropsychiatr Genet 168: 586-594. doi:10.1002/ajmg.b.32336
Nicolas G, Pottier C, Charbonnier C, Guyant-Marechal L, Le Ber I, Pariente $\mathrm{J}$ et al (2013a) Phenotypic spectrum of probable and genetically-confirmed idiopathic basal ganglia calcification. Brain 136:3395-3407. doi:10.1093/brain/awt255

Nicolas G, Pottier C, Maltete D, Coutant S, Rovelet-Lecrux A, Legallic $\mathrm{S}$ et al (2013b) Mutation of the PDGFRB gene as a cause of idiopathic basal ganglia calcification. Neurology 80: 181-187. doi:10.1212/WNL.0b013e31827ccf34

Pedersen L, Johann SV, van Zeijl M, Pedersen FS, O'Hara B (1995) Chimeras of receptors for gibbon ape leukemia virus/feline leukemia virus $B$ and amphotropic murine leukemia virus reveal different modes of receptor recognition by retrovirus. J Virol 69:2401-2405

Salaün C, Gyan E, Rodrigues P, Heard JM (2002) Pit2 assemblies at the cell surface are modulated by extracellular inorganic phosphate concentration. J Virol 76:4304-4311

Salaün C, Marechal V, Heard JM (2004) Transport-deficient Pit2 phosphate transporters still modify cell surface oligomers structure in response to inorganic phosphate. J Mol Biol 340:39-47. doi:10.1016/j.jmb.2004.04.050

Schottlaender L, Mencacci N, Koepp M, Hanna M, Hardy J, Lees A et al (2012) Interesting clinical features associated with mutations in the SLC20A2 gene. Eur J Neurol 19:40

Sobrido MJ, Coppola G, Oliveira J, Hopfer S, Geschwind DH (2014) Primary familial brain calcification. In: Pagon RA, Adam MP, Ardinger HH, Wallace SE, Amemiya A, Bean LJH, Bird TD, Ledbetter N, Mefford HC, Smith RJH, Stephens K (eds) GeneReviews $^{\mathrm{TM}}$. University of Washington, Seattle, WA

Taglia I, Mignarri A, Olgiati S, Menci E, Petrocelli PL, Breedveld GJ et al (2014) Primary familial brain calcification: genetic analysis and clinical spectrum. Mov Disord 29:1691-1695. doi:10.1002/mds.26053

Uckert W, Willimsky G, Pedersen FS, Blankenstein T, Pedersen L (1998) RNA levels of human retrovirus receptors Pit1 and Pit2 do not correlate with infectibility by three retroviral vector pseudotypes. Hum Gene Ther 9:2619-2627. doi:10.1089/hum.1998.9.17-2619

van Zeijl M, Johann SV, Closs E, Cunningham J, Eddy R, Shows TB et al (1994) A human amphotropic retrovirus receptor is a second member of the gibbon ape leukemia virus receptor family. Proc Natl Acad Sci U S A 91:1168-1172

Wagner CA, Friedrich B, Setiawan I, Lang F, Bröer S (2000) The use of Xenopus laevis oocytes for the functional characterization of heterologously expressed membrane proteins. Cell Physiol Biochem 10: $1-12$

Wallingford MC, Chia J, Leaf EM, Borgeia S, Chavkin NW, Sawangmake C et al (2016) SLC20A2 deficiency in mice leads to elevated phosphate levels in cerbrospinal fluid and glymphatic pathway-associated arteriolar calcification, and recapitulates human idiopathic basal ganglia calcification. Brain Pathol. doi:10.1111/bpa.12362

Wang C, Li YL, Shi L, Ren J, Patti M, Wang T et al (2012) Mutations in SLC20A2 link familial idiopathic basal ganglia calcification with phosphate homeostasis. Nat Genet 44:254256. doi:10.1038/ng.1077

Westenberger A, Klein C (2014) The genetics of primary familial brain calcifications. Curr Neurol Neurosci Rep 14:490. doi:10.1007/s11910-014-0490-4

Wider C, Dickson DW, Schweitzer KJ, Broderick DF, Wszolek ZK (2009) Familial idiopathic basal ganglia calcification: a challenging clinical-pathological correlation. J Neurol 256:839-842. doi:10.1007/s00415-009-5025-6

Yamada M, Tanaka M, Takagi M, Kobayashi S, Taguchi Y, Takashima S et al (2014) Evaluation of SLC20A2 mutations that cause idiopathic basal ganglia calcification in Japan. Neurology 82:705-712. doi:10.1212/WNL.0000000000000143 